\title{
Orthodontics as a therapeutic option for temporomandibular disorders: A systematic review
}

\author{
Eduardo Machado', Patricia Machado², Renésio Armindo Grehs ${ }^{3}$, Paulo Afonso Cunali ${ }^{4}$
}

Objective: Orthodontics as an option for treatment and prevention of Temporomandibular Disorders (TMD) is a topic that has generated discussion over time. While an occlusion current defends Orthodontics as an alternative to treatment, another current defends more conservative and reversible treatments. The objective of this study, through a systematic literature review, was to analyze the relationship between Orthodontics and TMD, checking the effects of orthodontic therapy in treatment and prevention of TMD.

Methods: Survey in research bases: MEDLINE, Cochrane, EMBASE, Pubmed, Lilacs and BBO, between the years of 1966 and May 2009, with focus in randomized clinical trials, non-randomized prospective longitudinal studies, systematic reviews and meta-analysis was performed.

Results: After application of the inclusion criteria 11 articles were selected, 9 which were non-randomized prospective longitudinal studies, 1 randomized clinical trial and 1 systematic review.

Conclusions: According to the literature, there is a lack of specific studies that evaluated Orthodontics as an option for treatment and prevention of TMD. Thus the data conclude that there is no significant scientific evidences that orthodontic treatment treats or prevents TMD.

Keywords: Temporomandibular joint dysfunction syndrome. Temporomandibular joint disorders. Craniomandibular disorders. Temporomandibular joint. Orthodontics. Dental occlusion.

\footnotetext{
${ }^{1}$ Specialist in Temporomandibular Disorders and Orofacial Pain, Federal University of Paraná. Graduated in Dentistry, Federal University of Santa Maria.

${ }^{2}$ Specialist in Prosthetic Dentistry, Pontifical Catholic University of Rio Grande do Sul. Graduated in Dentistry, Federal University of Santa Maria.

${ }^{3} \mathrm{PhD}$ in Orthodontics, UNESP. Professor of Graduation and Post-Graduation course in Dentistry, Federal University of Santa Maria.

${ }^{4} \mathrm{PhD}$ in Sciences, Federal University of São Paulo. Professor of Graduation and Post-graduation course in Dentistry, Federal University of Paraná. Coordinator of the Specialization course in TMD and Orofacial Pain, Federal University of Paraná.
}

How to cite this article: Machado E, Machado P, Grehs RA, Cunali PA. Orthodontics as a therapeutic option for temporomandibular disorders: A systematic review. Dental Press J Orthod. 2012 May-June;17(3):98-102.

Submitted: 31 de May 31, 2009 - Revised and accepted: August, 062009

» The authors report no commercial, proprietary or financial interest in the products or companies described in this article.

Contact address: Eduardo Machado

R. Francisco Trevisan, 20 - N. Sra. de Lourdes - Zip code: 97050-230

Santa Maria/RS - Brazil - E-mail: Eduardo@dtmedororofacial.com.br 


\section{INTRODUCTION}

The relationship between orthodontic treatment and Temporomandibular Disorders (TMD) consists of a subject that raises doubts about the real role of Orthodontics in treatment and prevention of TMD. In the recent past, dental occlusion was considered the main causal factor of TMD, and orthodontic treatment consisted a primary therapeutic measure for a physiologic restoration of the stomatognathic system. Over time, the etiology of TMD has been considered as multifactorial, being associated with other contributing factors such as the presence of parafunctional habits, anatomical and neuromuscular factors, systemic changes, psychological conditions and postural alterations., ${ }^{3,21}$

With the accomplishment of studies with adequate designs and precise and rigorous methodological criteria, the interface Orthodontics-TMD can be analysed critically. Thus, the general aim of this study, through a systematic literature review, was to analyse in a context of a scientific evidence based Dentistry, the inter-relation of TMD and Orthodontics, and specifically assess the effects of orthodontic therapy in the treatment and prevention of TMD.

\section{MATERIAL AND METHODS}

We performed a computerized search in MEDLINE, Cochrane, EMBASE, PubMed, Lilacs and BBO in the period from 1966 to May 2009. The research descriptors used were "orthodontics", "orthodontic treatment", "temporomandibular disorder," "temporomandibular joint", "craniomandibular disorder", "TMD," "TMJ," "malocclusion" and "dental occlusion", which were crossed in search engines. The initial list of studies was subjected to review by two reviewers, who applied inclusion criteria to determine the final sample of articles, which were assessed by their title and abstract. If there was any disagreement between the results of the reviewers, a third appraiser would participate by reading the full version of the article.

Inclusion criteria for selecting articles were:

» Studies which evaluated the effectiveness of orthodontic treatment in the treatment and prevention of Temporomandibular Disorders (TMD), and in which Orthodontics was compared to no treatment, placebo, oral appliances, pharmacological treatment and physical and relaxation therapies.

» Studies in which orthodontic treatment is already completed in the samples.

» Randomized clinical trials (RCTs), non-randomized prospective longitudinal studies, systematic reviews and meta-analysis.

» Studies written in English and published between 1966 and May 2009.

Thus, we excluded case reports, case series, crosssectional studies, simple reviews and authors opinions, as well as studies in which the orthodontic treatment has not been completed.

\section{RESULTS}

After applying the inclusion criteria 11 studies were obtained and the Kappa index of agreement between reviewers was 1.00. Of these, nine were non-randomized prospective longitudinal studies, one was a randomized clinical trial and one was a systematic review (Fig 1).

The sample of selected articles are presented in Tables 1 and 2.

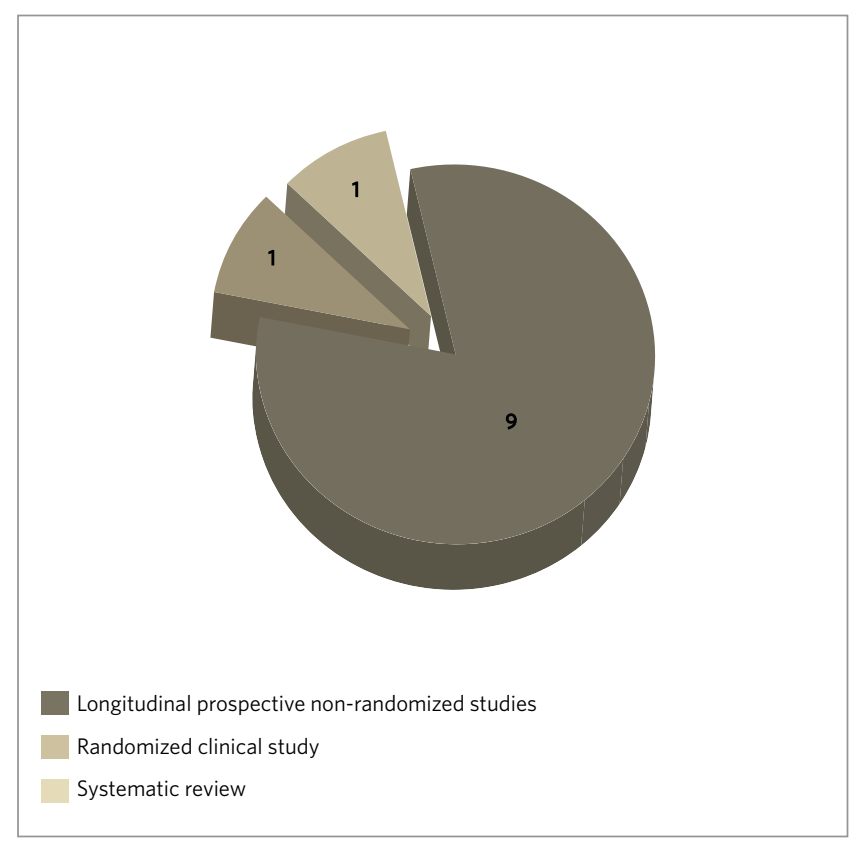

Figure 1 - Design of included studies. 
Table 1 - Included studies design.

\begin{tabular}{|c|c|c|c|c|c|}
\hline Authors & $\begin{array}{c}\text { Year of } \\
\text { publication }\end{array}$ & $\begin{array}{l}\text { Study } \\
\text { design }\end{array}$ & Sample size (N) & Control & $\begin{array}{c}\text { Orthodontic } \\
\text { appliance type }\end{array}$ \\
\hline Egermark and Thilander ${ }^{6}$ & 1992 & $P, L$ & 402 mixed & Yes & $\mathrm{FA}, \mathrm{F}$ \\
\hline Rendell et $\mathrm{al}^{22}$ & 1992 & $\mathrm{~L}$ & - 451 without TMD - 11 with TMD & No & $\mathrm{F}$ \\
\hline $\begin{array}{l}\text { Egermark and } \\
\text { Ronnerman }\end{array}$ & 1995 & $\mathrm{~L}$ & $50 \mathrm{tt}-135$ no tt & Yes & $F A, F$ \\
\hline Keeling et $\mathrm{al}^{15}$ & 1995 & RCT & 60 tt Bionator - 71 tt $\mathrm{AEB}-60$ no tt & Yes & FA \\
\hline Olsson and Lindqvist ${ }^{20}$ & 1995 & $P, L$ & $210 \mathrm{tt}$ & No & $\mathrm{F}$ \\
\hline Mcnamara and Turp ${ }^{17}$ & 1997 & SR & 21 studies & - & $\mathrm{FA}, \mathrm{F}$ \\
\hline Henrikson et al ${ }^{13}$ & 1999 & $P, L$ & $65 \mathrm{tt}$ & No & $\mathrm{F}$ \\
\hline Henrikson and Nilner ${ }^{11}$ & 2000 & $P, L$ & $65 \mathrm{tt}-58$ no tt (Class II) - 60 no tt (normal) & Yes & $\mathrm{F}$ \\
\hline Henrikson et $\mathrm{al}^{14}$ & 2000 & $P, L$ & 65 tt - 58 No tt (Class II) - 60 no tt (normal) & Yes & $F$ \\
\hline Henrikson and Nilner ${ }^{12}$ & 2003 & $P, L$ & $65 \mathrm{tt}-58$ no tt (Class II) -60 no tt & Yes & $\mathrm{F}$ \\
\hline Mohlin et al ${ }^{18}$ & 2004 & $\mathrm{P}, \mathrm{CC}$ & 72 without TMD - 62 with TMD & Yes & $F A, F$ \\
\hline
\end{tabular}

P: prospective, L: longitudinal, RCT: randomized clinical trial; SR: systematic review; CC: case-control; tt: treatment, F: fixed appliances; FA: functional appliances; H: headgear; NS: Not specified.

Table 2 - Included studies Results

\begin{tabular}{|c|c|c|c|c|}
\hline Authors & Time of assessment & Diagnostic criteria for TMD & Main objective of the study & $\begin{array}{l}\text { Relationship between } \\
\text { Orthodontics and TMD }\end{array}$ \\
\hline $\begin{array}{l}\text { Egermark and } \\
\text { Thilander }^{6}\end{array}$ & 10 years & $\begin{array}{l}\text { Questionnaire, Helkimo } \\
\text { index }\end{array}$ & $\begin{array}{l}\text { TMD prevalence in patients } \\
\text { orthodontically treated and untreated }\end{array}$ & $\begin{array}{l}\text { Treated patients: Lower } \\
\text { prevalence of TMD }\end{array}$ \\
\hline Rendell et $\mathrm{al}^{22}$ & During tt & Helkimo index & Orthodontics as a risk factor for TMD? & $\begin{array}{c}\text { Improvement in patients with } \\
\text { TMD }\end{array}$ \\
\hline $\begin{array}{l}\text { Egermark and } \\
\text { Ronnerman }\end{array}$ & Before, during, after $\mathrm{tt}$ & $\begin{array}{l}\text { Questionnaire, Helkimo } \\
\text { index }\end{array}$ & $\begin{array}{l}\text { TMD prevalence in patients } \\
\text { orthodontically treated and untreated }\end{array}$ & $\begin{array}{c}\text { Improvement of the signs } \\
\text { and symptoms of TMD and } \\
\text { headaches }\end{array}$ \\
\hline Keeling et a $\left.\right|^{15}$ & Follow-up of 2 years & $\begin{array}{l}\text { TMJ sound and pain, muscle } \\
\text { pain }\end{array}$ & Orthodontics as a risk factor for TMD? & $\begin{array}{l}\text { Bionator: improvements in } \\
\text { capsular pain in some children }\end{array}$ \\
\hline $\begin{array}{l}\text { Olsson and } \\
\text { Lindqvist }^{20}\end{array}$ & After $t t$ & $\begin{array}{l}\text { Questionnaire, Helkimo } \\
\text { index }\end{array}$ & $\begin{array}{l}\text { Influence of orthodontic treatment on } \\
\text { mandibular function }\end{array}$ & $\begin{array}{c}\text { Improvement in patients with } \\
\text { TMD }\end{array}$ \\
\hline $\begin{array}{l}\text { Menamara and } \\
\text { Turp }^{17}\end{array}$ & - & - & $\begin{array}{c}\text { The role of Orthodontics in the } \\
\text { development, prevention and treatment } \\
\text { of TMD }\end{array}$ & $\begin{array}{l}\text { Lack of reliable scientific } \\
\text { evidence }\end{array}$ \\
\hline Henrikson et al ${ }^{13}$ & $\begin{array}{l}\text { Before, during, after } \\
\text { tt and } 1 \text { year after 1st } \\
\text { evaluation }\end{array}$ & Signs and symptoms & $\begin{array}{l}\text { Prevalence of signs and symptoms of } \\
\text { TMD before, during and after tt }\end{array}$ & $\begin{array}{l}\text { Decrease in symptoms and } \\
\text { muscle sensitivity to palpation }\end{array}$ \\
\hline $\begin{array}{l}\text { Henrikson and } \\
\text { Nilner }\end{array}$ & $\begin{array}{l}2 \text { years after } 1 \text { st } \\
\text { evaluation }\end{array}$ & $\begin{array}{l}\text { Symptoms (headaches, } \\
\text { pain, TMJ sound) }\end{array}$ & $\begin{array}{c}\text { Prevalence of TMD symptoms in } \\
\text { patients orthodontically treated and not } \\
\text { treated }\end{array}$ & $\begin{array}{l}\text { Improvement of symptoms } \\
\text { of TMD }\end{array}$ \\
\hline Henrikson et a $1^{14}$ & $\begin{array}{l}2 \text { years after 1st } \\
\text { evaluation }\end{array}$ & $\begin{array}{l}\text { Signs (mandibular } \\
\text { movements, pain, TMJ } \\
\text { sound) }\end{array}$ & $\begin{array}{l}\text { Prevalence of TMD signs in patients } \\
\text { orthodontically treated and not treated }\end{array}$ & $\begin{array}{l}\text { Improvement of signs of } \\
\text { muscle TMD }\end{array}$ \\
\hline $\begin{array}{l}\text { Henrikson and } \\
\text { Nilner }\end{array}$ & $\begin{array}{l}\text { Beginning, after } 1 \text { and } \\
2 \text { years of } t \mathrm{t} \text { and } 1 \text { year } \\
\text { after the end of } t t\end{array}$ & Signs and symptoms & $\begin{array}{c}\text { Prevalence of TMD signs and symptoms } \\
\text { in patients orthodontically treated and } \\
\text { not treated }\end{array}$ & $\begin{array}{l}\text { Improvement of signs and } \\
\text { symptoms of muscle TMD }\end{array}$ \\
\hline Mohlin et a ${ }^{18}$ & $\begin{array}{c}\text { Performed at } 19 \text { and } 30 \\
\text { years old }\end{array}$ & $\begin{array}{l}\text { Questionnaire, clinical } \\
\text { assessment, psychological } \\
\text { status }\end{array}$ & $\begin{array}{c}\text { The role of Orthodontics in the } \\
\text { development, prevention and treatment } \\
\text { of TMD }\end{array}$ & $\begin{array}{c}\text { Without evidence that } \\
\text { Orthodontics is a preventive } \\
\text { therapy for TMD }\end{array}$ \\
\hline
\end{tabular}

tt: treatment; MM: mandibular movements; NS: not specified. 


\section{DISCUSSION}

The knowledge about the methodological criteria that qualify the scientific research becomes increasingly necessary in the current context of a scientific evidence based Dentistry. Thus, appropriate study designs, associated with methodological criteria such as randomization, calibration, sample size calculation, blinding, control factors, pairings for sex and age, among others, qualify the evidence generated and provide more precise scientific information. ${ }^{23}$ This knowledge is important, since most publications in national journals are studies of low potential for direct clinical application. ${ }^{19}$

Likewise, the design of clinical trials allows a qualification of scientific evidence generated. Cross-sectional studies allow the study of associations that identify risk indicators and generate hypotheses. Subsequently, these hypotheses need to be tested in longitudinal studies to identify true risk factors ${ }^{24}$. Due to this fact, the methodology of this systematic review included only longitudinal studies, systematic reviews and meta-analysis.

The results of this systematic review demonstrate a very limited number of specific studies about the role of orthodontic treatment in patients with signs and symptoms of TMD. Much of the selected studies aimed to evaluate first Orthodontics as a causal factor for the development of TMD, and secondarily to verify its role in the prevention and treatment of TMD. With this lack of clinical studies and significant evidences, such as RCTs, systematic reviews and meta-analysis, it becomes difficult to obtain accurate conclusions and extrapolate the results to the general population.

Some studies were suggestive of improvement in cases of TMD due to orthodontic treatment.,5,6,11-15,20,22 However, the results of these publications are subjective, since the main objective of most of these studies was to assess the prevalence of TMD in patients treated or not treated orthodontically ${ }^{5,6,11-14}$ or evaluate Orthodontics as possible risk factor for development of TMD. ${ }^{15,22}$ Thus, these publications had limitations, due to its main objective and the sample size of patients with pretreatment TMD. Still, other studies have proposed to specifically assess Orthodontics as a therapeutic option for muscular TMD, but as there was no revaluation at the end of treatment, they were not included in this systematic review. ${ }^{1,2}$
The studies that suggest a lower prevalence of TMD in orthodontically treated patients when compared to untreated individuals, showed greater benefit in muscle TMD, ${ }^{12,13,14}$ while only one study related improvements in joint pain ${ }^{15}$ In relation to the preventive role of orthodontic treatment in the development of TMD, some studies correlate this association in a positive ${ }^{6}$ and others in a negative way. ${ }^{17,18}$ But the systematic analysis of the literature demonstrates a lack of specific scientific evidence about the performance of orthodontic treatment in the treatment and prevention of TMD. ${ }^{17,18}$

Still, there is need for further controlled randomized clinical trials with rigorous methodological criteria and with the specific objective of assessing orthodontic therapy as a treatment option in patients with TMD. However, the difficulty of conducting RCTs involving Orthodontics and TMD is known, due to ethical and practical reasons ${ }^{16}$. Moreover, it is important to adopt universal and standardized diagnostic criteria for TMD, which would contribute to reducing the heterogeneity of the results obtained in various studies, since there are different diagnostic criteria: Craniomandibular Index, ${ }^{7,8}$ Helkimo Index, ${ }^{9,10}$ variations and adaptations of these and more recently the RDC/TMD. ${ }^{4}$

Therapies that change the occlusal pattern in a definitive manner, such as orthodontic treatment and occlusal adjustment, are not indicated and supported by significant scientific evidences as initial protocols of treatment for TMD. In patients with Temporomandibular Disorders conservative and reversible treatments as the initial protocol should be adopted, and then after their control and management, check the necessity of providing orthodontic procedures and prosthetic rehabilitation.

\section{CONCLUSIONS}

" There is no specific evidence based on randomized clinical trials, systematic reviews and meta-analysis, that orthodontic therapy is a therapeutic option for treatment, control and prevention of TMD.

» Some studies have demonstrated improvement in signs and symptoms of TMD in patients undergoing orthodontic treatment when compared to individuals who did not 
receive Orthodontics. However, these results are only suggestive, since it had limitations in relation to sample size and the main objective of the study.

" There is a need to assess Orthodontics as treatment and as prevention option for TMD based on studies with appropriate designs and rigorous methodological criteria. Thus, the relationship between Orthodontics and TMD should be based on controlled randomized clinical trials, systematic reviews and meta-analysis for more precise conclusions.

\section{REFERENCES}

1. Castroflorio T, Talpone F, Deregibus A, Piancino MG, Bracco P. Effects of a functional appliance on masticatory muscles of young adults suffering from muscle-related temporomandibular disorders. J Oral Rehabil. 2004 Jun;31(6):524-9.

2. Castroflorio T, Titolo C, Deregibus A, Debernardi C, Bracco P. The orthodontic treatment of TMD patients: EMG effects of a functional appliance. Cranio. 2007 Jul;25(3):206-12

3. Conti PCR. Oclusão e disfunções craniomandibulares (DCM): a eterna controvérsia. Revista ODONS. 1990 Dez 30;1:4.

4. Dworkin SF, LeResche L. Research diagnostic criteria for temporomandibular disorders: review, criteria, examinations and specifications, critique. J Craniomandib Disord. 1992 Fall;6(4):301-55.

5. Egermark I, Rönnerman A. Temporomandibular disorders in the active phase of orthodontic treatment. J Oral Rehabil. 1995 Aug;22(8):613-8.

6. Egermark I, Thilander B. Craniomandibular disorders with special reference to orthodontic treatment: an evaluation from childhood to adulthood. Am J Orthod Dentofacial Orthop. 1992 Jan;101(1):28-34

7. Fricton JR, Schiffman EL. The reliability of a craniomandibular index. J Dent Res. 1986 Nov;65(11):1359-64.

8. Fricton JR, Schiffman EL. The craniomandibular index. Validity. J Prosthet Dent. 1987 Aug;58(2):222-8.

9. Helkimo M. Studies on function and dysfunction of the masticatory system. II. Index for anamnestic and clinical dysfunction and occlusal state. Sven Tandlak Tidskr. 1974 Mar;67(2):101-21.

10. Helkimo M. Studies on function and dysfunction of the masticatory system. III. Analyses of anamnestic and clinical recordings of dysfunction with the aid of indices. Sven Tandlak Tidskr. 1974 May;67(3):165-81.

11. Henrikson T, Nilner M. Temporomandibular disorders and need of stomatognathic treatment in orthodontically treated and untreated girls. Eur J Orthod. 2000 Jun;22(3):283-92.

12. Henrikson T, Nilner M. Temporomandibular disorders, occlusion and orthodontic treatment. J Orthod. 2003 Jun;30(2):129-37; discussion 127.

13. Henrikson T, Nilner M, Kurol J. Symptoms and signs of temporomandibular disorders before, during and after orthodontic treatment. Swed Dent J. 1999;23(5-6):193-207.
14. Henrikson T, Nilner M, Kurol J. Signs of temporomandibular disorders in girls receiving orthodontic treatment. A prospective and longitudinal comparison with untreated Class II malocclusions and normal occlusion subjects. Eur J Orthod. 2000 Jun;22(3):271-81.

15. Keeling SD, Garvan CW, King GJ, Wheeler TT, McGorray S. Temporomandibular disorders after early Class II treatment with bionators and headgears: results from a randomized controlled trial. Semin Orthod. 1995 Sep;1(3):149-64.

16. Kim MR, Graber TM, Viana MA. Orthodontics and temporomandibular disorder: A meta-analysis. Am J Orthod Dentofacial Orthop. 2002 May;121(5):438-46.

17. McNamara JA Jr, Türp JC. Orthodontic treatment and temporomandibular disorders: is there a relationship? Part 1: clinical studies. J Orofac Orthop. 1997;58(2):74-89.

18. Mohlin BO, Derweduwen K, Pilley R, Kingdon A, Shaw WC, Kenealy P. Malocclusion and temporomandibular disorder: a comparison of adolescents with moderate to severe dysfunction with those without signs and symptoms of temporomandibular disorder and their further development to 30 years of age. Angle Orthod. 2004 Jun;74(3):319-27.

19. Oliveira GJ, Oliveira ES, Leles CR. Tipos de delineamento de pesquisa de estudos publicados em periódicos odontológicos brasileiros. Rev Odonto Ciênc. 2007 Jan-Mar;22(55): 42-7.

20. Olsson M, Lindqvist B. Mandibular function before and after orthodontic treatment. Eur J Orthod. 1995 Jun;17(3):205-14.

21. Parker MW. A dynamic model of etiology in temporomandibular disorders. J Am Dent Assoc. 1990 Mar;120(3):283-90.

22. Rendell JK, Norton LA, Gay T. Orthodontic treatment and temporomandibular disorders. Am J Orthod Dentofacial Orthop. 1992 Jan;101(1):84-7.

23. Susin C, Rosing CK. Praticando odontologia baseada em evidências. Canoas: ULBRA; 1999.

24. Susin C, Rosing CK. A importância do treinamento, reprodutibilidade e calibragem para a qualidade dos estudos. Rev Fac Odontol Porto Alegre. 2000; 40(2):3-6. 